\title{
Low-grade neuroendocrine tumor of the corpus uteri
}

INSERM

\section{Source}

INSERM. (1999). Orphanet: an online rare disease and orphan drug data base. Low-grade neuroendocrine tumor of the corpus uteri. ORPHA:213736

Low-grade neuroendocrine tumor of the corpus uteri is an extremely rare uterine cancer typically characterized by a well demarcated, solid, frequently pedunculated tumor originating from neuroendocrine cells scattered within the endometrium, often associated with ectopic hormone production. Patients usually present with vaginal bleeding or discharge and a pelvic mass with a polypoid tumor sometimes protruding through the cervical canal. Symptoms related to ectopic hormone production (flushing, sweating, diarrhea, bronchospasm) may also develop. 